\title{
Samisk folkemedisin
}

\begin{abstract}
I Tidsskriftet nr. 1/1933 anmeldte den språkmektige legen og medisinhistorikeren Ingjald Reichborn-Kjennerud (1865-1949) en av utgivelsene til den enda mer språkmektige læreren, etnografen, kulturhistorikeren, teologen og ministeren Just Qvigstad (1853-1957). I tråd med tidens fornorskingspolitiske klima er det kanskje ikke så rart at det ut fra filologiske argumenter hevdes at samenes folkemedisin er «frukten av et innsig fra deres grannefolk av germansk rase». Men det spennende samiske - sjamanisme, noaider, runebommer - er ikke så lett å finne igjen i overleveringene fra de gamle nordmenns trolldomsmedisin (Tidsskr Nor Lægeforen 1933; 53: 19-21).
\end{abstract}

\section{Bokanmeldelser.}

J . Q v i g s t a d: Lappische Heilkunde. Instituttet for sammenlignende kulturforskning, Oslo 1932.

Det folkemedisinske materiale som er samlet i dette skrift av rektor Qvigstad, vår fremragende forsker av finsk-ugrisk sprog og kultur, er hentet ikke bare fra Nord-Norge, men også fra de nordlige deler av Sverige, Finland og Russland hvor det bor stammefrender av dette folk som kaller sig selv samer, men vi finner (ikke å forveksle med kvænene som er av finnlandsk avstamning) og som på svensk og flere andre sprog heter lapper. Qvigstads kilder er både en rekke eldre kilder om samefolkets liv og en hel del nyere optegnelser av ham selv og hans hjelpere, særlig lærere og mere fremstående «innfødte». Også flere læger er med blant hans hjemmelsmenn, som fhv. distriktslæge A. B. Wessel i Sørvaranger og tyskeren dr. med. L. Kohl som i hele fem år var kst. distriktslæge i Tana og har skrevet om samenes lægemetoder i Münchener med. Wochenschr. 1926. Nærværende anmelder som i en årrekke tjenstgjorde som læge i Nord-Norge, har også ydet noget bidrag. Hertil kommer at Q. har gjort flittig bruk av lægenes artikler $\mathrm{i}$ «Medisinalberetningen» som er en sann gullgrube for den som vil studere vår folkemedisin.

Det innsamlede materiale kaster et grellt lys over dette spørsmål som enhver av oss er tilbøielig til å stille : har dette folk en helt egenartet lægekunst fra gammel tid, eller er deres folkemedisin frukten av et innsig fra deres grannefolk av germansk rase? De utførlige anmerkninger som Q. har forsynt sitt arbeide med, viser at det meste stammer fra nordmenn og svensker, og det er merker som tyder på at påvirkningen er skjedd alt i meget gammel tid. Dette ser vi ved at en del sykdomsnavn og anatomiske navn må være lånt fra gammelnorsk, da de ikke tilhører til nutidens tungemål ; men flere av dem finner vi igjen i nynorsken.

Et av samenes ord for blod svarer til oldnorskens dreyri, deres navn på meslinger, $\mathrm{r} \mathfrak{x} \mathrm{w} \mathrm{d}$ o eller $\mathrm{k}$ r æ w d o, til gno. krefðusótt (bygdemålenes kregda eller kredda), b o a k k o, kopper, til nyno. poka (tysk Pocken), h a w g e, sting, til nyno. hogg, v a r k a eller $\mathrm{v} æ \mathrm{r} \mathrm{k} \mathrm{a,}$ smerte, til nyno. verk, r i v u n eller r i b u n, utslett, til nyno. riva eller ribba («rever») o. s. v. Særlig interessant er et av deres ord for sykdom i sin alminnelighet, d a w d a, som er gno. dauði, egtl. død eller dødelig sykdom. «Dauen» er ennu somme steder sørpå navnet på den farligste av alle sykdommer, nemlig den som fører til døden. Et av samenes ord for kardialgi svarer til det nynorske skirva eller skjerva som egentlig er et ord for processus ensiformis.

Det vil imidlertid føre for vidt å gå nærmere inn på det utsyn som dette og mere annet gir over samenes arv fra vår gamle folkemedisin. Jeg skal ennu bare peke på at vi her også finner spor av den allestedsnærværende hippokratiske medisin, f. eks. i deres fødselshjelp.

Det sier sig selv at dette ennu til en viss grad primitive folk også må ha en særegen folkemedisin, bl. a. av den grunn at deres lægeråd må være knyttet til deres miljø og den stedegne tilgang på hjelpemidler fra de tre naturriker. Det er rimelig at de ofte søker dem hos sitt

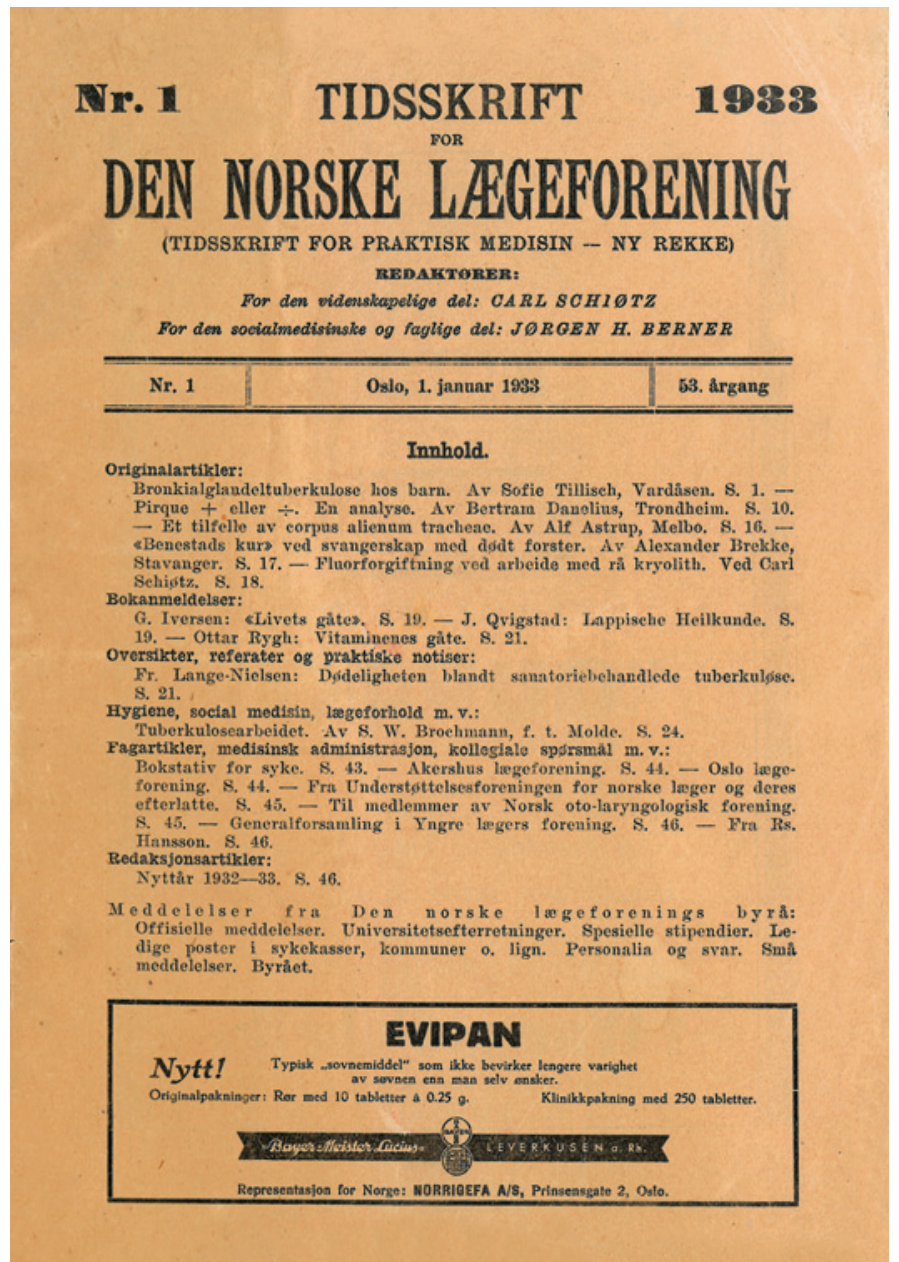

viktigste husdyr, reinen, og blant havets dyr. Av schamanismen, deres magiske medisin, av noaidens, medisinmannens bruk av trolltrommen for å søke hjelp hos de døde, er det ikke stort igjen i vår tid. Skjønt vi i denne magi møter flere drag som vi ikke finner igjen i overleveringene fra de gamle nordmenns trolldomsmedisin, er det dog slike likhetspunkter, at vi heller ikke uten videre kan regne denne som helt egen for samefolket.

Enhver læge som interesserer sig for folkedypets tanker om helse og sykdom, vil ha stor interesse av å lese Qvigstads bok. 